\title{
Population structure and conservation of endangered Citrus indica Yu.Tanaka (Rutaceae) in Behali Reserve Forest of Assam, India
}

\author{
Dipankar Borah ${ }^{2}$, Parixit Kafley ${ }^{1}$, Sumpam Tangjang and A.P. Das \\ Department of Botany, Rajiv Gandhi University, Rono Hills, Doimukh 791112, Arunachal Pradesh, India \\ ${ }^{1}$ Nature's Bonyopran, Bedeti, Biswanath 784176, Assam, India \\ ${ }_{2}^{2}$ Author for correspondence, e-mail: dipankarborah085@gmail.com; dipankar.borah@rgu.ac.in
}

Received 20.10.2018; Revised 06.12.2018; Accepted 12.12.2018; Published 31.12.2018

\begin{abstract}
The occurrence of endangeed plant, Citrus indica Yu.Tanaka (Rutaceae) was recorded from the Behali Reserve Forest in assam, India. Its distribution pattern, association and status in Northeast India, prospect and possible methods of proper conservation has been discussed in the article.
\end{abstract}

Key words: Citrus indica, Behali Reserve Forest, Status, Conservation

\section{INTRODUCTION}

The genus Citrus L. (Rutaceae) and its related genera Eremocitrus Swingle, Fortunella Swingle, Microcitrus Swingle and Poncirus Raf. are belonging to subfamily Aurantioideae and are widely scattered across the monsoonal regions from west Pakistan to North-central China and south through the East Indian Archipelago to New Guinea and the Bismarck Archipelago, Northeastern Australia, New Caledonia, Melanesia and the western Polynesian islands (Swingle \& Reece 1967). East Asia comprising Northeast India (earlier Assam), northern Myanmar and western Yunnan in the foothills of the Himalayas is considered to be one of the centres of origin of Citrus species. During the late Miocene, a sudden speciation event have led to the diversification of branches of the ancestral Citrus species, and this radiation has enabled the shift of the genus into drier regions from the wet monsoon climate (Wu et al. 2018).

Recent studies by Sharma et al. (2004), Malik et al. (2006) and Hazarika (2012) on genetic resources of Citrus in Northeastern India indicated the presence of 23 species, 1 subspecies and 68 varieties, and hence this area still attains a special status as a treasure house of Citrus germplasm. Seven species of Citrus are still growing in wild and semi-wild conditions in small pockets of the Northeast Indian region as Citrus indica Yu.Tanaka, $C$. hystrix DC. $(=C$. macroptera Montrouz.), C. latipes (Swingle) Yu.Tanaka, $C$. megaloxycarpa Lush., C. medica L., Citrus cavaleriei H.Lév. ex Cavalerie (=C. ichangensis Swingle) and C. assamensis R.M.Dutta \& Bhattacharya and listed as endangered by threat perception analysis as per IUCN norms (Singh \& Singh 2003; Malik et al. 2006).

Citrus indica 'Indian wild orange' recognized by Tanaka in 1928, is believed to be the most primitive of all the Citrus species and the progenitor of the cultivated ones (Singh 1981). Tanaka (1937) stated 'It is really a wild citrus found in Nowgong (Nagaon) district, 
Khasi hills and Manipur in Assam'. According to Singh (1981), the plant is endemic to Northeastern Himalayas and reported to be occurring wild in Naga Hills of Nagaland, Garo Hills of Meghalaya and Kaziranga Reserve Forest in Assam. But, the recent surveys reported its presence only in Tura range of Garo Hills of Meghalaya (Upadhyay \& Sundriyal 1998; Singh \& Singh 2003; Malik et al. 2006). The species is somewhat cultivated in Garo Hills as the fruits are used medicinally and also a fruit is kept on the dead body before cremation to keep away the from affecting the relatives (Malik et al. 2006).

\section{Behali Reserve Forest:}

Behali Reserve Forest (BRF) is situated in the Biswanath District of the state of Assam, India, bordering the state of Arunachal Pradesh, and with central coordinates $26^{\circ} 54^{\prime} 32^{\prime \prime} \mathrm{N}$ and $93^{\circ} 18^{\prime} 29^{\prime \prime} \mathrm{E}$ and the altitude varies from $80-100 \mathrm{~m}$ amsl. The area of the BRF is 14016 ha and the vegetation type is mainly forested, evergreen and semi-evergreen types. However, Kushwaha and Hazarika (2004) with their Remote Sensing mapping treated these forests as moist deciduous and degraded. About 3,375, ha area of BRF is encroached by various groups of people namely Nepali, Karbi, Bodo and Tea-tribes. However, even today, some areas of the reserve is still covered with good natural vegetation (Bora 2001).

\section{Present survey:}

During the ongoing floristic and phytosociological surveys of Behali Reserve Forest (BRF) a patch of Citrus indica was encountered in a moist tract of primary forest. The patch covers only $20 \mathrm{~m}^{2}$ area and there are seven plants, of which three are with only flowers, two with fruits and flower-buds, one sapling and one old plant of which the main stem was cut-off and new shoots (coppices) are coming out from base. To record the presence of any other population within the BRF, an additional $10 \mathrm{~km}^{2}$ area were surveyed and the information collected from forest-dependent people of the nearby villages were analysed but no more plant was detected.

Another wild species, Citrus medica is known to have distribution all over the country (Singh \& Chadha 1993) in warmer regions. This species is also found in BRF. Vavilov (1950) have noticed the occurrence of Citron (C. medica) in wild, as well as in cultivation during his visit to North-east India. It has also a good distribution in the BRF, but restricted towards south in deciduous open scrubs, or along the river-banks, whereas, C. indica is restricted only in the northern part of the forest at the geographical location $26^{\circ} 53^{\prime} 25^{\prime \prime} \mathrm{N}$ latitude and $93^{\circ} 15^{\prime} 80^{\prime \prime}$ E longitude.

\section{Taxonomic treatment:}

Citrus indica Yu. Tanaka, Stud. Citrol. 2: 164. 1929; Fl. India 4: 281 - 282.

\section{Local name: 'Memang Narang' [= Ghost orange in Garo language (Singh 1981)]}

Shrubs to $3 \mathrm{~m}$ high; branchlets terete, glabrous, dark green, turns brownish with age, spreading; thorns short, upto $1 \mathrm{~cm}$ long, dark green with brown tip. Leaves unifoliate; petioles $1.5-2.0 \mathrm{~cm}$ long, slightly winged, articulated at apex; lamina oblonglanceolate to elliptic-oblong, $6.5-11.0 \times 2.5-5.0 \mathrm{~cm}$, sub-entire to shallowly crenate, shortly caudate-obtuse, base attenuate and finally rounded, $2^{\circ}$ veins $5-7$ pairs, prominent abaxially, oblique, alternate. Flowers solitary, rarely in pairs, axillary; pedicels c. $4 \mathrm{~mm}$ long, glabrous, greenish white; flowers male and bisexual, monoecious; calyx cupular with $4-5$ minute lobes, deltoid, conspicuously pellucid-punctate abaxially; petals 5, oblong, $10-18 \times 2-6 \mathrm{~mm}$, obtuse, glandular, white with yellowish tinge; stamens $22-25$, in three whorls, innermost whorl shortest; filaments united one third of the length, free above, glabrous, white; anthers $1-3 \mathrm{~mm}$ long, introrse; ovary vase 

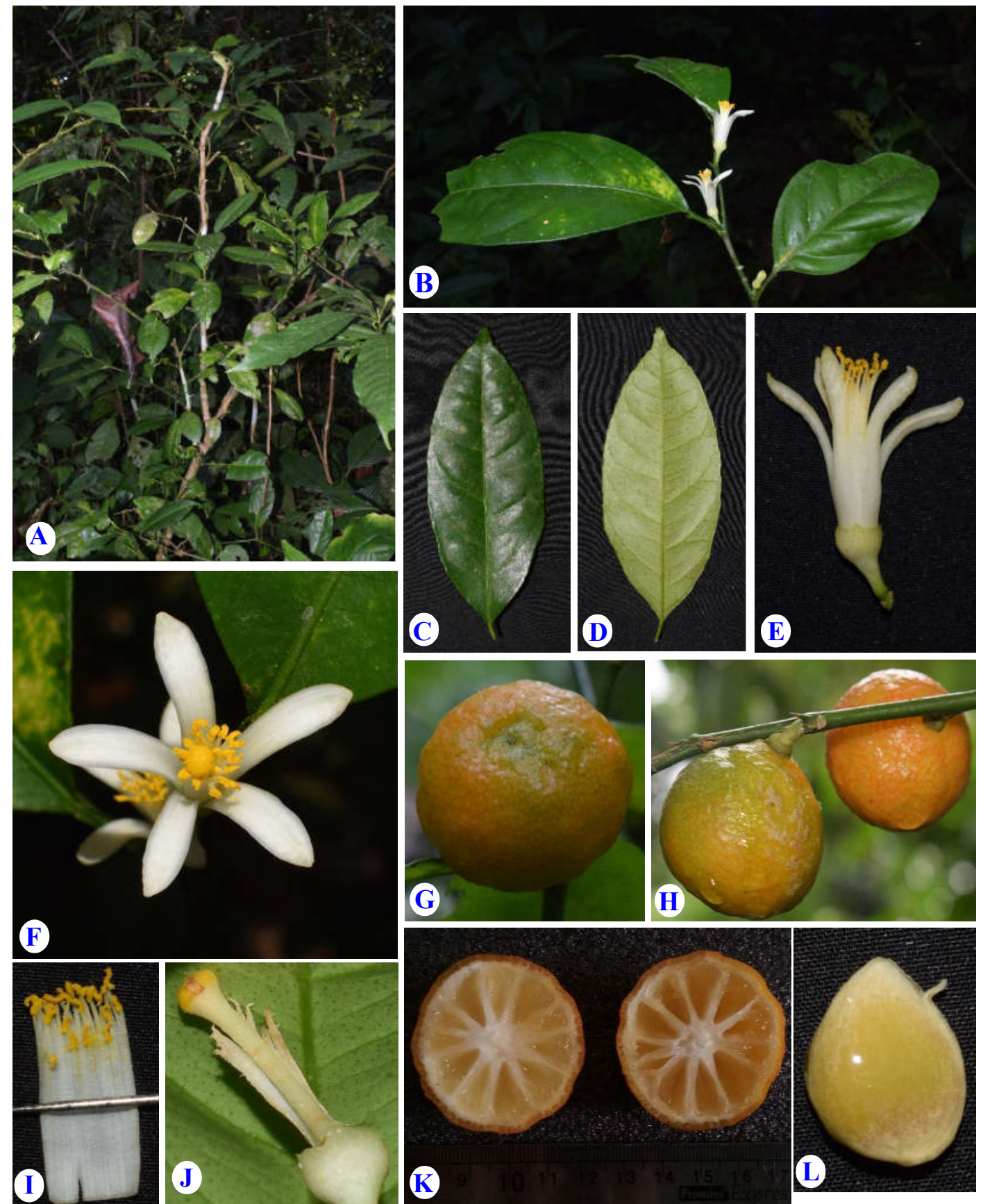

PLATE - I. Citrus indica Yu. Tanaka (Rutaceae): A. Whole Plant; B. A flowering twig; C. Lamina adaxial surface; D. Lamina abaxial surface; E. Flower in side view; F. Flower in top view; G \& H. Fruits in different views; I. Stamens; J. Style and stigma; K. Fruit sliced transversely through the middle; L. Seed. [Photos: Dipankar Borah]

shaped, 8 - 11 locular; style terete, white; stigma capitate. Fruits globose to obovoid, $4-5 \mathrm{~cm}$ across, depressed-obtuse at apex, base cuneate, smooth, glandular, deep orange to scarlet red when ripe, pericarp thin, slightly adherent; mesocarp thin, soft, 
white; endocarp segments $8-11$; juicy pulps yellowish white, fusiform or polygonal, stalked, shiny, juice scanty, sour; seeds $5-7$ per fruit, ovoid, flattened, $12-15 \times 8$ $\mathrm{mm}$, smooth, cotyledons green.

Flowering: October to November

Fruit ripening: September to October

Distribution: Nair \& Nayar (1997) in Flora of India recorded its distribution in Northeastern India covering states on Assam, Manipur, Meghalaya and Nagaland. However, population structure is quite small.

Associated species: The dominant tree species around the Citrus indica population includes Magnolia hodgsonii (Hook.f. \& Thomson) H.Keng, Morus macroura Miq., Bauhinia variegata L., Elaeocarpus sp, and Actinodaphne obovata (Nees) Blume in the top storey; shrubs and under-shrubs like Chloranthus elatior Link, Coffea benghalensis B.Heyne ex Schult. Sterculia lanceolata var. coccinea (Jack) Phengklai, Clerodendrum laevifolium Blume, Dalhousiea bracteata (Roxb.) Graham ex Benth., Gnetum gnemon L., Phanera macrostachya Benth., Phlogacanthus sp, and Dracaena petiolata Hook.f.; climbers like Xanthoxylum sp, Dioscorea spp, Dalbergia sp, Caesalpinia crista L., Smilax blumei A.DC., and in the herb or ground covering layer Oplismenus burmanni (Retz.) P.Beauv., Mycetia nutans (R.Br. ex Kurz) Razafim. \& B.Bremer, Tropidia curculigoides Lindl., Tacca integrifolia Ker Gawl., Amischotolype hookeri (Hassk.) H.Hara, etc. are forming rich but slightly open vegetation in its habitat.

\section{Threats to Citrus indica in Behali Reserve Forests}

Behali Reserve Forest is housing many endangered and rare plants such as Canarium strictum, Morus macroura (Meena et al. 2012) including the Indian wild orange, Citrus indica. But the future of this species is a matter of concern as the primary tracts of forest in the region is very scarce and is facing high pressure due to illegal logging, extensive firewood collection, extension of human habitation and their too much dependence on forest products. Encroachment is a great concern and causing threat to the local wildlife as well. The area is located within the important elephant corridor for large scale migration (Kushwaha \& Hazarika 2004). Out of BRF's total geographical area of $140.16 \mathrm{~km}^{2}, 60$ $\mathrm{km}^{2}$ is already encroached and the remaining $80.16 \mathrm{~km}^{2}$ is also under anthropogenic exploitation. As it appeared, $C$. india is a poor coloniser and under the present situation in BRF the increase of its population and expansion of habitat area seems to be difficult. Eventually, under the present situation, the species is now confined to single small patch within the entire BRF.

Personal interviews and open ended discussions with the people of surrounding and nearby villages and forest officials produced very less information on the utility of the plant, except its ripe fruits are sometimes eaten by locals. However, Nair \& Nayar (1997) mentioned that fruits are inedible but the species can be used as root-stock for propagation of cultivated species.

\section{Conservation issues}

Aiming at the conservation of this wild citrus, in situ conservation practice seems to be the best possible option for the present study area as it was already reported that seedgrown cultivated plants do not flower in spite of their healthy vegetative growth, indicating its low adaptation to manmade habitats (Zeven \& de Wet 1982). C. indica is a plant with 
reports of use, intricate into the lives of Garo people in Meghalaya (Malik et al. 2006), though its known use in the present forest is yet to be evaluated. Its conservation as an important gene-pool resource in developing better cultivars in the future is understood. Moreover, it is clear that the elimination of this species, as well as its associated species will impact the overall stability of the ecosystem. In literature there is no record of its propagation through air-layering, but if it is successful, then its propagation can be faster and immediate flowering is expected.

\section{DISCUSSION AND CONCLUSION}

Citrus indica has been observed to be hardy and to be free from pests and diseases in its natural habitat (Malik et al. 2006). And if proper utilisation of this resistibility is necessitated it can provide good results (rootstocks, cultivated varieties) as most interspecific Citrus hybrids are fertile. to fast decline of the primary tracts of forests, these wild endangered plants need special and immediate attention for conservation due to their endemism and high degree of threat perception (Malik et al. 2006; Hynniewta et al. 2014). To protect these invaluable genetic resources of citrus, initiative was taken way back in 1981 by establishing the Citrus Gene Sanctuary in the Garo Hills of Meghalaya covering an area of about 10,266 hectares and is probably first of its kind in the world (Singh 1981), is endowed with highly specified microclimate with a combination of tropical and mild temperate seasons and experiencing very high humidity and rainfall.

Very soon other places holding the wild populations in North-east India should also to be conserved understanding its cultural and scientific importance. Behali Reserve Forest is just one such area, which holds a number of such rare and endangered floral wealth. Endowed with much suitable climatic conditions, the vegetation of BRF varies right from deciduous tropical forests to riparian forests and Tropical mixed forests. All these corresponds in creating a suitable microclimate, compared to the surrounding areas. Proposals for increasing the protection of the area, production of its viable seedlings or saplings and re-establishing those in the wild, in similar microclimatic condition, in addition to recognizing BRF as a in situ 'Citrus Sanctuary' is to be done immediately.

\section{LITERATURE CITED}

Bora, M.C. 2001. Natural Resource Management: Sustainable Extraction Level of Forest Products in Assam. Theme: CPRs and Forests, EERC Working Paper Series: CPR3. Indira Gandhi Institute of Development Research, Mumbai.

Hazarika, T.K. 2012. Citrus genetic diversity of north-east India, their distribution, ecogeography and ecobiology. Genet. Resour. Crop Evol. 59: 1267 - 1280. DOI 10.1007/s10722-012-9846-2

Hynniewta, M.; Malik, S.K. \& Rao, S.R. 2014. Genetic diversity and phylogenetic analysis of Citrus (L) from north-east India as revealed by meiosis, and molecular analysis of internal transcribed spacer region of rDNA. Meta Gene 2: 237 - 251. http://dx.doi.org/ 10.1016/j.mgene.2014.01.008. PubMed

Kushwaha, S.P.S. \& Hazarika, R. 2004. Assessment of habitat loss in Kameng and Sonitpur Elephant Reserves. Curr. Sci. 87(10): $1447-1453$.

Malik, S.K.; Chaudhury, R.; Dhariwal, O.P.; Kalia, R.K. 2006. Collection and characterization of Citrus indica Tanaka and C. macroptera Montr. : wild endangered species of northeastern India. Genet. Resour. Crop. Evol. 53: 1485 - 1493. 
Meena, D.; Binaibabu, N. \& Doss, J. 2012. Future prospects for the critically endangered medicinally important species, Canarium strictum Roxb. : a review. Intn. J. Consv. Sci. 3(3): $231-237$.

Nair, K.N. \& Nayar, M.P. 1997. Rutaceae. In: Hajra, P.K.; Nair, V.J. \& Daniel, P. Flora of India. Vol. 4. Botanical Survey of India, Calcutta. Pp. 278 - 282.

Sharma, B.D.; Hore, D.K. \& Gupta, S.G. 2004. Genetic resources of Citrus of north-eastern India and their potential use. Genet. Resour. Crop Evol. 51: 411 - 418.

Singh, B. 1981. Establishment of First Gene Sanctuary for Citrus in Garo Hills. Concept Publishing Company, New Delhi.

Singh, H.P. \& Chadha, K.L. 1993. Genetic resources of Citrus. In: Chadha, K.L. \& Pareek, O.P. (eds.), Advances in Horticulture, Vol 1. Fruit crops. Malhotra Publishing House, New Delhi. Pp. $95-121$.

Singh I.P. \& Singh S. 2003. Exploration, collection and mapping of citrus genetic diversity in India. Technical Bulletin No.7, National Research Centre for Citrus, Nagpur.

Swingle, W.T. \& Reece, P.C. 1967. The botany of Citrus and its wild relatives. In: W. Reuther, L.D. Batchelor \& H.J. Webber (eds.), The Citrus Industry. University of California Press, Berkeley. Pp. 190 - 340.

Tanaka, T. 1928. On certain new Species of citrus. Studia Citrologica 2: 155 - 164.

Tanaka, T. 1937. Citrus fruits of India. Allahabad Farmer 2: 53 - 57.

Upadhyay, R.C. \& Sundriyal, R.C. 1998. Crop gene pools in the Northeast Indian Himalayas and threats. In: T. Pratap \& B. Sthapit (eds.), Managing Agrobiodiversity-Farmers Changing Perspective and Institutional Responses in the Hindu Kush-Himalayan Region. ICIMOD \& IPGRI, Kathmandu, Nepal. Pp. 167 - 173.

Vavilov, N.I. [translated by K.S. Chester] 1950. Pytogeographic Basis of Plant Breeding. Chron. Bot. 13 (1/6): $13-54$.

Wu, G.A.; J. Terol, V.; Ibanez, A.; López-García, E.; Pérez-Román, C.; Borredá, C.; Domingo, F.R.; Tadeo, J.; Carbonell-caballero, R.; Alonso, F.; Curk, D.; Du, P.; Ollitrault, M.L.; Roose, J.; Dopazo, F.G.; Gmitter Jr, D.S.; Rokhsar \& Talon, M. 2018. Genomics of the origin and evolution of Citrus. Nature. doi:10.1038/nature25447.

Zeven, A.C. \& de Wet, J.M.J. 1982. Dictionary of Cultivated Plants and Their Regions of Diversity. Centre for Agricultural Publishing and Documentation, Wageningen, The Netherlands. 